\title{
EFEKTIVITAS UNDANG-UNDANG NOMOR 11 TAHUN 2008 TENTANG INFORMASI DAN TRANSAKSI ELEKTRONIK TERHADAP PROPAGANDA DI INDONESIA
}

\author{
Wilton Goh* \\ PT Gunung Mas Valasindo
}

\begin{abstract}
In the case of Buni Yani's propaganda that spread the video of Basuki Tjahaja Purnama alias Ahok's speech which was carried out in a campaign with an explanation of Surat Al Maidah 51. Buni Yani modified the video and uploaded it to his Facebook page by adding caption. The Buni Yani's actions result in hatred or hostility of Muslims against Basuki Tjahaja Purnama whose ethnicity is Chinese and non-Muslim. The purpose of this study is to analyze and describe Buni Yani propaganda action and to examine the effectiveness of Law Number 11 of 2008 Concerning Electronic Information And Transactions in handling propaganda matters in Indonesia especially in the Basuki Tjahaja Purnama and Buni Yani case. This research is normative legal research, therefore it uses a secondary data from books, journals, research result, internet sources. It uses the Law Effectiveness Theory to resolve propaganda electronic information effectively and efficiently.
\end{abstract}

Keywords: propaganda, video, electronic transaction, law.

\begin{abstract}
Abstrak
Pada kasus propaganda Buni Yani yang menyebarkan video pidato Basuki Tjahaja Purnama alias Ahok yang dilakukan dalam menjalani kampanye dengan penjelasan tentang Surat Al Maidah 51. Buni Yani melakukan rekayasa terhadap video tersebut dan diunggahkan ke laman Facebook-nya dengan menambahkan caption. Perbuatan Buni Yani tersebut mengakibatkan kebencian atau permusuhan umat Islam terhadap Basuki Tjahaja Purnama yang beretnis Tionghoa dan beragama non Islam. Tujuan dari penelitian ini adalah untuk menganalisis dan menguraikan perbuatan propaganda Buni Yani dan menganalisis efektivitas Undang-Undang Nomor 11 Tahun 2008 Tentang Informasi dan Transaksi Elektronik dalam menangani persoalan propaganda di Indonesia khusus dalam kasus Basuki Tjahaja Purnama dan Buni Yani. Penelitian ini merupakan penelitian hukum normatif yang menggunakan data sekunder yang diperoleh buku, jurnal, hasil penelitian, penelusuran internet. Penelitian ini menggunakan teori efektivitas hukum untuk mengatasi informasi elektronik yang bersifat propaganda secara efektif dan efesien.
\end{abstract}

Kata kunci: propaganda, video, transaksi elektronik, hukum.

\footnotetext{
*Alamat Korespondensi : wu.wilton@live.com
} 


\section{A. Latar Belakang Masalah}

Pada Undang-Undang Nomor 11 Tahun 2008 tentang Informasi dan Transaksi Elektronik pada huruf c berbunyi, "bahwa perkembangan dan kemajuan Teknologi Informasi yang demikian pesat telah menyebabkan perubahan kegiatan kehidupan manusia dalam berbagai bidang yang secara langsung telah memengaruhi lahirnya bentuk-bentuk perbuatan hukum baru". ${ }^{1}$ Dari pernyataan tersebut, maka dapat disimpulkan bahwa secara globalisasi, teknologi informasi dan komunikasi telah mempengaruhi sifat masyarakat dan peradaban manusia. Selain itu, perkembangan teknologi informasi telah mengakibatkan dunia tanpa batas (bordeless) dan mengakibatkan perubahan yang sangat cepat dan signifikan terhadap kehidupan sosial. Teknologi informasi sekarang ini telah berubah menjadi sebuah pedang bermata dua, selain memberikan keuntungan bagi pertumbuhan kesejahteraan, kemajuan dan peradaban manusia, sekaligus menjadi sarana efektif untuk melakukan perbuatan yang melanggar hukum. ${ }^{2}$

Sudah sejak lama propaganda menjadi masalah yang rawan dan kompleks. Jika semakin dibiarkan akan menjadi semakin tidak terkontrol dan akan menimbulkan pro dan kontra. Bagi sebagian orang menganggap propaganda hanyalah sebuah informasi ataupun pesan yang biasa dalam kehidupan sehari-hari. Tetapi di satu sisi propaganda dianggap sebuah informasi ataupun pesan yang telah direkayasa bersifat provokasi sehingga dapat menimbulkan keributan ataupun kekacauan pada masyarakat yang mempercayainya.

Seperti pada kasus Buni Yani yang menyebarkan video pidato Basuki Tjahaja Purnama alias Ahok yang dilakukan dalam menjalani kampanye dengan penjelasan tentang Surat Al Maidah 51. Buni Yani melakukan rekayasa terhadap video tersebut dan diunggahkan ke laman Facebook-nya dengan menambahkan caption. Perbuatan Buni Yani tersebut mengakibatkan kebencian atau permusuhan umat Islam terhadap Basuki Tjahaja Purnama yang beretnis Tionghoa dan beragama non Islam atau beragama Kristen. ${ }^{3}$

Berdasarkan latar belakang tersebut peneliti tertarik untuk meneliti ini dengan judul "EFEKTIVITAS UNDANG-UNDANG NOMOR 11 TAHUN 2008 TENTANG INFORMASI DAN TRANSAKSI ELEKTRONIK TERHADAP PROPAGANDA DI INDONESIA".

\section{B. Perumusan Masalah}

a. Apakah perbuatan Buni Yani terhadap Basuki Tjahaja Purnama dapat dikualifikasikan sebagai propaganda?

\footnotetext{
${ }^{1}$ Undang-Undang Nomor 11 Tahun 2008 tentang Informasi dan Transaksi Elektronik.

2 Ahmad M. Ramli, Cyber Law \& Haki Dalam Sistem Hukum Indonesia, Bandung: PT Refika Aditama, 2010, hlm. 1.

${ }^{3}$ Dody Indra Ramadhan, Caption Budi Yani di Facebook Disebut Sebarkan Permusuhan Sara, 2017.
} 
b. Apakah Undang-Undang Nomor 11 Tahun 2008 Tentang Informasi dan Transaksi Elektronik efektif dalam menangani persoalan propaganda di Indonesia khusus dalam kasus Basuki Tjahaja Purnama dan Buni Yani?

c. Selain faktor hukum, apa ada faktor lain yang efektif untuk menangani persoalan propaganda di Indonesia?

\section{Metode Penelitian}

Dalam tesis ini, peneliti akan menggunakan penelitian yuridis normatif atau yang biasa disebut dengan hukum normatif, karena data yang diambil dan diteliti oleh peneliti adalah data yang diambil berasal dari penelitian kepustakaan yang merupakan data sekunder. Hukum normatif adalah hukum yang memberi pemahaman terhadap permasalahan norma yang dialami oleh ilmu hukum dogmatik dalam kegiatannya mendeskripsikan norma hukum, merumuskan norma hukum (membentuk peraturan perundang-undangan), dan menegaskan norma hukum (praktik yudisial). ${ }^{4}$

Menurut Soerjono Soekanto, metode penelitian hukum dapat penelitian hukum kepustakaan dan penelitian hukum empiris atau penelitian hukum sosiologis. Penelitian hukum normatif (yuridis) dilakukan hanya dengan meneliti bahan pustaka atau data sekunder sedangkan penelitian hukum empiris atau penelitian sosiologis dilakukan dengan cara meneliti data primer. ${ }^{5}$ Sehubungan penelitian ini adalah penelitian hukum normatif, maka data yang digunakan adalah data sekunder berupa bahan hukum primer, yaitu Undang-Undang Nomor 11 Tahun 2008 tentang Informasi dan Transaksi Elektronik. Sedangkan bahan hukum sekunder, yaitu buku, makalah, artikel, majalah, jurnal hukum, laporan hasil penelitian, komentar atas putusan pengadilan dan karya ilmiah bahkan dokumen pribadi atau pendapat dari kalangan pakar hukum yang berhubungan dan relevan dengan objek penelitian yang dilakukan. Dan bahan hukum tersier, yaitu kamus bahasa Indonesia, kamus bahasa inggris, ensiklopedia, Wikipedia, internet, situs tertentu yang diakui dan lain-lain.

Data sekunder dalam penelitian hukum normatif diperoleh dengan menggunakan studi kepustakaan atau literatur, penelusuran internet, klipping Koran dan/atau studi dokumentasi berkas-berkas penting dari institusi yang diteliti serta penelusuran peraturan perundang-undangan dari berbagai sumber yang berhubungan dengan masalah penelitian. ${ }^{6}$ Dalam penelitian ini penulis menggunakan analisis deskriptif terhadap data kualitatif yang pada dasarnya

\footnotetext{
${ }^{4}$ I Made Pasek Diantha, Metodologi Penelitian Hukum Normatif Dalam Justifikasi Teori Hukum, Jakarta: Prenada Media Group, 2016, hlm. 84.

${ }^{5}$ Soerjono Soekanto, Pengantar Penelitian Hukum, Jakarta: Penerbit Universitas Indonesia (UIPress), 1986, hlm. 52.

${ }^{6}$ Agus Cik, Dampak Pemberlakuan Perjanjian Penghindaran Pajak Berganda (P3B) Terhadap Investasi Negara Investor Asing Di Kota Batam, Tesis Magister Hukum, tidak diterbitkan, Universitas Internasional Batam, Kota Batam, hlm. 87.
} 
menggunakan pemikiran secara logis dengan induksi, deduksi, komparasi dan interprestasi. $^{7}$

\section{Hasil Penelitian dan Pembahasan}

Kasus Basuki Tjahaja Purnama dan Buni Yania terjadi bermula dari Basuki Tjahaja Purnama menjalani kegiatan kunjungan kerja ke Kepulauan Seribu, Jakarta, pada 27 September 2016. Pada saat itu, Basuki Tjahaja Purnama berdialog dengan masyarakat di daerah tersebut dan juga menebarkan 4.000 benih ikan. ${ }^{8}$

Dalam video pidato resmi Pemerintah Provinsi DKI Jakarta melalui YouTube, Basuki Tjahaja Purnama memberikan penjelasan tentang program nelayan yang sedang dilakukan oleh Pemerintah Provinsi DKI Jakarta. ${ }^{9}$ Basuki Tjahaja Purnama meminta masyarakat di daerah tersebut agar tidak merasa khawatir terhadap program tersebut tidak terlaksanakan jika Basuki Tjahaja Purnama tidak terpilih lagi dan juga mengutip Surat Al Maidah ayat 51. ${ }^{10}$

Basuki Tjahaja Purnama mengutip: ${ }^{11}$

"Jadi jangan percaya-percaya sama orang. Kan bisa saja dalam hati kecil Bapak Ibu, gak bisa pilih saya. Ya kan? Dibohongi pakai Surat Al Maidah ayat 51."

Buni Yani mengunduh video pidato Ahok yang diunggah oleh Diskominfomas Pemprov DKI Jakarta pada Kamis, 06 Oktober 2016. Setelah itu, Buni Yani mengurangi durasi video yang awalnya 1 jam 48 menit menjadi 30 detik atau tepatnya di antara menit ke 24.00 sampai dengan menit ke $25.00{ }^{12}$

Video yang telah diubah itu lalu diunggah Buni Yani ke laman Facebook-nya. Buni Yani juga menambahkan caption di laman Facebook-nya itu yaitu: ${ }^{13}$

"Penistaan terhadap Agama? 'Bapak-Ibu [pemilih muslim]...dibohongi Surat Al Maidah 51'... [dan]'masuk neraka[juga bapak-ibu]dibodohi.' Kelihatannya akan terjadi sesuatu yang kurang baik dengan video ini."

Menurut Jaksa Andi Muh. Taufik terhadap kasus tersebut bahwa dengan menghilangkan kata 'pakai' dan menambahkan caption tersebut, sehingga perbuatan Buni Yani tersebut menimbulkan kebencian atau permusuhan umat Islam terhadap Basuki Tjahaja Purnama alias Ahok yang beretnis Tionghoa dan beragama non Islam atau beragama Kristen. Dengan tambahan caption tersebut mengakibatkan adanya reaksi dari masyarakat khususnya umat Islam yang dapat menimbulkan kebencian dan permusuhan yang menjurus pada terganggunya kerukunan antar umat beragama di Indonesia. ${ }^{14}$

\footnotetext{
${ }^{7}$ Philemon Ginting, Kebijakan Penanggulanagan Tindak Pidana Teknologi Informasi Melalui Hukum Pidana, Universitas Diponegoro, Semarang, hlm. 21.

${ }^{8}$ Dedy Rahmadi, Kasus Penistaan Agama Oleh Ahok Sehingga Dibui 2 Tahun, 2017

${ }^{9}$ Srihandriatmo Malau, Ini Kisah Perjalanan Kasus Ahok Hingga Vonis 2 Tahun Penjara, 2017.

${ }^{10}$ Rahmadi, Loc.Cit.

${ }^{11}$ Malau, Loc.Cit.

${ }^{12}$ Dody Indra Ramadhan, Caption Budi Yani di Facebook Disebut Sebarkan Permusuhan Sara, 2017

13 Ibid.

${ }^{14}$ Ibid.
} 
Pada 07 Oktober 2016, Habib Novel Chaidir Hasan melaporkan Basuki Tjahaja Purnama. Laporan Polisi Nomor LP/1010/X/2016 Bareskrim tersebut berisi laporan penghinaan agama. Basuki Tjahaja Purnama telah menjadi tersangka dalam melakukan tindak pidana penghinaan agama melalui media elektronik di YouTube. $^{15}$

Dalam proses laporan tersebut, demonstrasi dan desakan dari masyarakat bermunculan dari berbagai wilayah. Aksi besar-besaran di Jakarta pada 04 November 2016 mengakibatkan Basuki Tjahaja Purnama ditolak ketika kampanye Pilkada DKI 2017 di beberapa wilayah Jakarta. ${ }^{16}$

Beberapa masyarakat menuntut polisi untuk segera memproseskan perkara Basuki Tjahaja Purnama dengan tuntutan penistaan agama. Basuki Tjahaja Purnama juga bersedia menjalani pemeriksaan berulang kali di kepolisian dan juga mengupayakan meminta maaf kepada masyarakat secara terbuka. ${ }^{17}$

Pada 14 Oktober 2016, Video yang diunggah oleh Buni Yani menjadi rujukan aksi ratusan orang dari Front Pembela Islam (FPI) yang berdemonstrasi di Balai Kota DKI Jakarta. Dalam Ketua FPI Muhammad Rizieq berkata akan membunuh Basuki Tjahaja Purnama jika polisi tidak menangkap Basuki Tjahaja Purnama. ${ }^{18}$

Karena Gerakan massa yang semakin kuat mengakibatkan gangguan terhadap keamanan dan ketertiban masyarakat (kamtibmas), Presiden Joko Widodo menginstruksikan kepada Kapolri agar segera mengelarkan proses kasus Basuki Tjahaja Purnama secara terbuka dan transparan.

Pada 16 November 2016, Basuki Tjahaja Purnama ditetapkan sebagai tersangka dalam kasus penistaan agama. ${ }^{19}$

Pada 23 November 2016, Pertama kali Buni Yani diperiksa atas laporan Komunitas Advokat Pendukung Ahok-Djarot (Kotak Adja) terhadap UndangUndang Nomor 11 Tahun 2008 tentang Informasi dan Transaksi Elektronik dan berdasarkan hasil pemeriksaan dan penyelidikan, polisi menetapkan Buni Yani sebagai tersangka penghasutan SARA. ${ }^{20}$

Pada 05 Desember 2016, Buni Yani mengajukan gugatan praperadilan karena tidak terima dirinya menjadi tersangka atas kasus dugaan penyebaran informasi yang mengandung rasa kebencian atau permusuhan berdasarkan SARA sebagaimana Pasal 28 ayat (2) Undang-Undang Nomor 11 Tahun 2008 tentang Informasi dan Transaksi Elektronik. ${ }^{21}$

\footnotetext{
${ }^{15}$ Rita Ayuningtyas, Mengulik Kembali Perjalanan Kasus Ahok, 2018

16 Ibid.

${ }^{17}$ Ibid.

${ }^{18}$ Gilang Fauzi, Kronologi Kasus Buni Yani, Penyebar Video Ahok Soal Al Maidah, 2016

${ }^{19}$ Malau, Loc.Cit.

${ }^{20}$ Fauzi, Loc.Cit.

${ }^{21}$ Kanavino Ahmad Rizqo, Perjalanan Kasus Buni Yani Sampai Jaksa Menuntut 2 Tahun Bui, 2017
} 
Pada 13 Desember 2016, Persidangan perdana Basuki Tjahaja Purnama dilaksanakan di bekas Pengadilan Negeri Jakarta Pusat, Gajah Mada, Jakarta Pusat. Basuki Tjahaja Purnama didakwa melanggar Pasal 156 huruf a KUHP dan Pasal 156 KUHP. ${ }^{22}$

Pada 21 Desember 2016, Hakim tunggal Setiyono menolak permohonan praperadilan yang diajukan Buni Yani dan penetapan tersangka oleh polisi telah dinilai telah sah dan sesuai prosedur. ${ }^{23}$

Pada 20 April 2017, Jaksa Penuntut Umum (JPU) menuntut Basuki Tjahaja Purnama bersalah dan satu tahun penjara dengan masa percobaan selama dua tahun. $^{24}$

Pada 09 Mei 2017, Hakim Ketua Dwiarso Budi Santiarto menyatakan Basuki Tjahaja Purnama terbukti secara sah dan meyakinkan bersalah dalam melakukan tindak pidana penodaan agama, penjara dua tahun. ${ }^{25}$

Pada 03 Oktober 2017, Buni Yani dituntut oleh jaksa dengan pidana penjara selama dua tahun dan denda seratus juta rupiah atau tiga bulan kurungan. ${ }^{26}$

Pada 14 November 2017, Majelis hakim Pengadilan Negeri Bandung memvonis satu setengah tahun penjara kepada Buni Yani. Ketua Majelis Hakim, M Saptono menganggap Buni Yani secara sah dan meyakinkan bersalah atas perbuatannya dalam melakukan tindak pidana terkait UndangUndang Nomor 11 Tahun 2008 tentang Informasi dan Transaksi Elektronik. ${ }^{27}$

Untuk mengetahui perbuatan Buni Yani terhadap Basuki Tjahaja Purnama dapat dikualifikasi sebagai propaganda harus didahului dengan mengetahui pengertian dari informasi elektronik dan pengertian dari propaganda.

Pengertian informasi elektronik sudah sangat signifikan dan jelas sebagaimana telah diterangkan pada Pasal 1 Angka 1 Undang-Undang Nomor 11 Tahun 2008 Tentang Informasi dan Transaksi Elektronik yang mendefinisikan informasi elektronik sebagai "satu atau kumpulan data elektronik, termasuk tetapi tidak terbatas pada tulisin, suara, gambar, peta, rancangan, foto, electronic data interchange (EDI), surat elektronik (electronic mail), telegram, teleks, telecopy atau sejenisnya, huruf, tanda, angka, Kode Akses, simbol, atau perforasi yang telah diolah yang memiliki arti atau dapat dipahami oleh orang yang mampu memahaminya". ${ }^{28}$

Dari definisi informasi elektronik pada Pasal 1 Angka 1 Undang-Undang Nomor 11 Tahun 2008 Tentang Informasi dan Transaksi Elektronik telah menjelaskan karakteristik yang dapat dikualifikasikan sebagai suatu informasi elektronik.

${ }^{22}$ Ayuningtyas, Loc.Cit.

${ }^{23}$ Rizqo, Loc.Cit.

${ }^{24}$ Ibid.

${ }^{25}$ Ibid.

${ }^{26}$ Rizqo, Loc.Cit.

${ }^{27}$ Kartika Anggraeni, Perjalanan Kasus Buni Yani Hingga Vonis 1,5 Tahun Bui, 2017

${ }^{28}$ Undang-Undang Nomor 11 Tahun 2008 Tentang Informasi dan Transaksi Elektronik. 
Selanjutnya juga melakukan pemahaman terhadap pengertian propaganda. Dari beberapa pengertian propaganda yang telah disajikan pada Bab II, dapat dimengertikan bahwa propaganda adalah sarana untuk merebut dan mengelola kekuasaan. Maka itu, dalam melancarkan propaganda, pertama yang harus dikuasai adalah pengetahuan. Tanpa pengetahuan, ide tidak akan bisa mengambil alih kekuasaan. Meskipun ide harus dipertahankan secara kokoh dan tetap, propaganda harus fleksibel, sesuai dengan kondisi atau berlaku saat propaganda dilancarkan. Propaganda boleh jadi mengatakan hal-hal yang berbeda di sana-sini, tergantung siapa yang menjadi targetnya. Propaganda terhadap kondektur dan pengemudi angkutan umum bisa berbeda dengan propaganda terhadap pengusaha atau pejabat negara. Poster atau pidato propagandis yang ditujukan kepada petani berbeda dengan yang ditujukan kepada pegawai, dokter, advokat, insinyur, dan sebagainya. Jika tidak berbeda, orang akan menilai propaganda itu sebagai sebuah lelucon yang tidak dapat dipahami. Propaganda harus bisa memperoleh apa yang dipandang penting di mata banyak orang. ${ }^{29}$

Menurut Joseph Goebbels berpendapat, propaganda tidak dilakukan untuk menemukan orang-orang yang setuju dengan sejumlah teori atau argumentasi ilmiah, tetapi untuk menemukan orang-orang yang bersedia menerima apa yang dipandang benar; itulah hal mendasar dalam propaganda. Karena pertimbangan itu, propaganda harus dilancarkan dengan menggunakan metode yang layak. ${ }^{30}$ Menurut Lindsley Fraser, propaganda memiliki karakteristik sebagai berikut: ${ }^{31}$

1. Bidang propaganda tidak terbatas pada bidang kehidupan tertentu. Contohnya propaganda pada bidang politik yang sering dipraktikkan oleh partai atau kelompok penekan yang berupaya membujuk publik agar memberikan dukungan terhadap kegiatan politiknya, propaganda sosialkeagamaan yang sering dipraktikkan oleh kalangan misionaris, dan propaganda ekonomi berupa iklan yang disiarkan produsen.

Propaganda, baik yang bersifat politik, ekonomi, maupun sosial, seharusnya bermuatan nilai-nilai moral karena tujuannya adalah menyuntikkan standar pelaku terhadap massa selaras dengan nilai-nilai moral yang berlaku di tengah massa yang menjadi targetnya, jika tidak demikian, terbuka kemungkinan massa akan menolaknya. Tetapi pada praktiknya, propaganda kerap dibuat sebatas nilai-nilai moral yang dipercayai propagandis itu sendiri.

2. Propaganda bertujuan memengaruhi orang banyak sehingga mereka bersedia melakukan tindakan sebagaimana dikehendaki, melalui kata-kata tanpa menggunakan paksaan atau kekerasan.

Menurut Joseph Goebbles bahwa propaganda sekurang-kurangnya memiliki karakteristik sebagai berikut: ${ }^{32}$

\footnotetext{
${ }^{29}$ Mohammad Shoelhi, Propaganda Dalam Komunikasi Internasional, Bandung: Simbiosa Rekatama Media, 2012, hlm. 40-41.

${ }^{30}$ Id. at 40 .

${ }^{31} \mathrm{Id}$. at 41-42.
} 
1. Propaganda harus populer, dikemas bukan untuk menyenangkan secara intelektual.

2. Propaganda bertujuan mentransmisikan pengetahuan yang khalayak.

3. Propaganda harus fleksibel, menyesuaikan diri dengan kondisi dan apa yang ingin dicapainya dengan pengetahuan.

4. Propaganda menggunakan metode yang layak.

5. Tercapainya tujuan propaganda tercermin dari perubahan sikap, pendapat, dan tindakan target propaganda sesuai yang dikehendaki propagandis.

Pada kasus Buni Yani yang menyebarkan video pidato Basuki Tjahaja Purnama mempunyai karakteristik propaganda seperti yang telah dijelaskan oleh peneliti yaitu:

1. Buni Yani menggunakan sosok Gubernur DKI Jakarta, Basuki Tjahaja Purnama yang sedang populer di Indonesia untuk melakukan propaganda.

2. Buni Yani menyebarkan video pidato Basuki Tjahaja Purnama tersebut menyerupai tujuan propaganda karena seperti yang dikatakan oleh Jaksa Andi Muh. Taufik, tujuan dari perbuatan Buni Yani adalah menimbulkan kebencian atau permusuhan umat Islam terhadap Basuki Tjahaja Purnama alias Ahok yang beretnis Tionghoa dan beragama non Islam atau beragama Kristen.

3. Propaganda yang dilakukan Buni Yani terebut sangat fleksibel karena Basuki Tjahaja Purnama sedang dalam menjalani kampanye pemilihan umum, dan Basuki Tjahaja Purnama yang beretnis Tionghoa dan beragama non Islam atau beragama Kristen dan juga melakukan pidato dalam menjalani kampanye dengan penjelasan tentang Surat Al Maidah 51. Dengan begini, Buni Yani mendapatkan kesempatan untuk melakukan propagandanya.

4. Dalam hal ini, perbuatan Buni Yani tersebut menyerupai metode propaganda yaitu Metode Fasilitatif.

5. Penyebaran video pidato Basuki Tjahaja Purnama oleh Buni Yani telah menghasilkan berbagai respon dari massa-massa dan perubahan sikap massa terhadap Basuki Tjahaja Purnama.

6. Selain itu, perbuatan Buni Yani menyerupai teknik-teknik propaganda yaitu Card Stacking (Menimbang-nimbang Kartu untuk Digunakan) dan Using All Forms of Persuations.

7. Komponen-komponen dari perbuatan Buni Yani menyerupai komponen propaganda dimana terdapat Komunikator yaitu Buni Yani, Komunikan yaitu massa-massa pengguna Facebook, Pesan yang telah dirumuskan yaitu video pidato Basuki Tjahaja Purnama, Target propaganda yaitu Basuki Tjahaja Purnama, Teknik-teknik propaganda yaitu Card Stacking (Menimbang-nimbang Kartu untuk Digunakan) dan Using All Forms of Persuations, Kondisi yang dilakukan saat tengah pemilihan umum Gubernur DKI Jakarta dan Basuki Tjaharja Purmana adalah salah satu calon legislatif, dan tujuan propaganda yang hendak dicapai yaitu menimbulkan rasa benci rakyat kepada Basuki Tjaharja Purnama.

${ }^{32}$ Id. at 41. 
Secara keseluruhan, kasus Budi Yani menyebar video pidato Basuki Tjahaja Purnama dapat dikualifikasikan sebagai perbuatan propaganda.

Maka dapat disimpulkan bahwa karakteristik perbuatan Buni Yani terhadap Basuki Tjahaja Purnama merupakan:

1. Pesan atau informasi yang dikategorikan sebagai Informasi Elektronik.

2. Propaganda yang sedang populer, dikemas bukan untuk menyenangkan secara intelektual.

3. Propaganda yang bertujuan.

4. Propaganda yang fleksibel, menyesuaikan diri dengan kondisi dan apa yang ingin dicapainya dengan pengetahuan.

5. Propaganda menggunakan metode yang layak.

6. Tercapainya tujuan propaganda atas perubahan sikap, pendapat, dan tindakan target propaganda sesuai yang dikehendaki propagandis.

7. Propaganda yang memiliki komponen propaganda.

8. Propaganda yang menggunakan teknik-teknik yang efektif sesuai dengan tujuan propaganda yang ingin dicapai.

Dalam pembahasan ini, peneliti menggunakan teori efektivitas hukum Soekanto Soerjono untuk mengukur sejauh mana efektivitas Undang-Undang Nomor 11 Tahun 2008 Tentang Informasi dan Transaksi Elektronik dalam menangani persoalan propaganda di Indonesia khusus dalam kasus Basuki Tjahaja Purnama dan Buni Yani dengan faktor-faktor sebagai berikut:

1. Faktor hukumnya sendiri (undang-undang)

Karena pembahasan berkaitan dengan informasi elektronik maka UndangUndang yang ditujukan adalah Undang-Undang Nomor 11 Tahun 2008 tentang Informasi dan Transaksi Elektronik.

Peneliti akan mengujikan kefektivitas Undang-Undang Nomor 11 Tahun 2008 tentang Informasi dan Transaksi Elektronik dalam menangani persoalan propaganda di Indonesia khusus dalam kasus Basuki Tjahaja Purnama dan Buni Yani.

Propaganda menganut dua prinsip buruk yang berlaku: ${ }^{33}$

a. Menyebarkan kebohongan kepada publik, selama publik tidak tahu dianggap tidak menjadi masalah.

b. Kebohongan yang diulang-ulang, akan membuat publik percaya. Sekurangkurangnya mampu mengecoh publik.

Selain itu, berdasarkan pengertian para ahli tentang propaganda yang telah disajikan oleh peneliti pada bab dua, dapat disimpulkan bahwa propaganda telah melanggar Pasal 35 Undang-Undang Nomor 11 Tahun 2008 tentang Informasi dan Transaksi Elektronik yang berbunyi: ${ }^{34}$

"Setiap Orang dengan sengaja dan tanpa hak atau melawan hukum melakukan manipulasi, penciptaan, perubahan, penghilangan, pengrusakan Infromasi Elektronik dan/atau Dokumen Elektronik dengan tujuan agar Informasi

${ }^{33}$ Shoelhi, Op.Cit., hlm 48.

${ }^{34}$ Undang-Undang Nomor 11 Tahun 2008 tentang Informasi dan Transaksi Elektronik. 
Elektronik dan/atau Dokumen Elektronik tersebut dianggap seolah-olah data yang otentik."

Pada sisi tujuan dari suatu propaganda dilancarkan untuk memengaruhi pikiran, perasaan, serta tindakan massa di manapun. ${ }^{35}$ Untuk bisa mencapai tujuan propaganda, tentu saja propaganda harus dirancang sedemikain rupa, tak terkecuali dengan memerhatikan teknik-teknik implementasinya secara tepat guna. ${ }^{36}$ Teknik-teknik yang dimaksud adalah teknik yang seefektif mungkin, yang dapat memberikan pengaruh dan mampu mendorong target propaganda melakukan sesuatu sesuai dengan keinginan atau pola yang ditentukan propagandis. ${ }^{37}$ Dalam hal ini, setiap teknik yang digunakan propagandis yang bertujuan untuk memengaruhi orang dalam mengakibatkan kerugian kepada orang lain, maka hal tersebut telah melanggar Pasal 36 Undang-Undang Nomor 11 Tahun 2008 tentang Informasi dan Transaksi Elektronik yang berbunyi: ${ }^{38}$

"Setiap Orang dengan sengaja dan tanpa hak atau melawan hukum melakukan perbuatan sebagaimana dimaksud dalam Pasal 27 sampai dengan Pasal 34 yang mengakibatkan kerugian bagi Orang Lain."

Contoh pada kasusnya Buni Yani menyebar video pidato Basuki Tjahaja Purnama, Buni Yani telah melakukan rekayasa video pidato Basuki Tjahaja Purnama dengan menghilangkan kata 'pakai' telah melanggar Pasal 32 ayat (1) Undang-Undang Nomor 11 Tahun 2008 tentang Informasi dan Transaksi Elektronik yang berbunyi: ${ }^{39}$

"Setiap Orang dengan sengaja dan tanpa hak atau melawan hukum dengan cara apa pun mengubah, menambah, mengurangi, melakukan transmisi, merusak, menghilangkan, memindahkan, menyembunyikan suatu Informasi Elektronik dan/atau Dokumen Elektronik milik Orang lain atau milik publik."

Dan Pasal 35 Undang-Undang Nomor 11 Tahun 2008 tentang Informasi dan Transaksi Elektronik yang berbunyi: ${ }^{40}$

"Setiap Orang dengan sengaja dan tanpa hak atau melawan hukum melakukan manipulasi, penciptaan, perubahan, penghilangan, pengrusakan Infromasi Elektronik dan/atau Dokumen Elektronik dengan tujuan agar Informasi Elektronik dan/atau Dokumen Elektronik tersebut dianggap seolah-olah data yang otentik."

Selain itu, Buni Yani juga menambahkan caption yang menimbulkan kebencian atau permusuhan umat Islam terhadap Basuki Tjahaja Purnama alias Ahok yang beretnis Tionghoa dan beragama non Islam atau beragama Kristen di laman Facebook-nya telah melanggar Pasal 27 ayat Undang-Undang Nomor 11 Tahun 2008 tentang Informasi dan Transaksi Elektronik yang berbunyi: ${ }^{41}$

\footnotetext{
${ }^{35}$ Id. at 50.

${ }^{36}$ Id. at 51 .

${ }^{37}$ Id. at $51-52$.

${ }^{38}$ Undang-Undang Nomor 11 Tahun 2008 tentang Informasi dan Transaksi Elektronik.

${ }^{39}$ Ibid

${ }^{40}$ Ibid

${ }^{41}$ Ibid
} 
"Setiap Orang dengan sengaja dan tanpa hak mendistribusikan dan/atau mentransmisikan dan/atau membuat dapat diaksesnya Informasi Elektronik dan/atau Dokumen Elektronik yang memiliki muatan penghinaan dan/atau pencemaran nama baik."

Dan Pasal 28 ayat (2) Undang-Undang Nomor 11 Tahun 2008 tentang Informasi dan Transaksi Elektronik yang berbunyi: ${ }^{42}$

"Setiap Orang dengan sengaja dan tanpa hak menyebarkan informasi yang ditujukan untuk menimbulkan rasa kebencian atau permusuhan individu dan/atau kelompok masyarakat tertentu berdasarkan atas suku, agama, ras, dan antargolongan (SARA)."

Dan Pasal 36 Undang-Undang Nomor 11 Tahun 2008 tentang Informasi dan Transaksi Elektronik yang berbunyi: ${ }^{43}$

"Setiap Orang dengan sengaja dan tanpa hak atau melawan hukum melakukan perbuatan sebagaimana dimaksud dalam Pasal 27 sampai dengan Pasal 34 yang mengakibatkan kerugian bagi Orang lain."

Secara keseluruhan dapat disimpulkan bahwa Undang-Undang Nomor 11 Tahun 2008 tentang Informasi dan Transaksi Elektronik efektik dalam menanggapi setiap kegiatan propaganda yang berakibat kerugian pada orang lain ataupun yang bertujuan kriminalitas.

\section{Faktor penegak hukum}

Penegak hukum memiliki peran yang sangat penting dalam menerapkan hukum yang berlaku. Dalam menangani kasus Basuki Tjahaja Purnama dan Buni Yani, Penegak hukum telah memvonis Buni Yani atas perbuatannya terhadap Basuki Tjahaja Purnama. Buni Yani dinilai telah melanggar Pasal 28 ayat (2) UndangUndang Nomor 11 Tahun 2008 tentang Informasi dan Transaksi Elektronik yang berbunyi: ${ }^{44}$

"Setiap Orang dengan sengaja dan tanpa hak menyebarkan informasi yan ditujukan untuk menimbulkan rasa kebencian atau permusuhan individu dan/atau kelompok masyarakat tertentu berdasarkan atas suku, agama, ras, dan antargolongan (SARA)."

Atas penyebaran video pidato Basuki Tjahaja Purnama melalui media sosial online yang bernama Facebook yang bertujuan menimbulkan kebencian atau permusuhan umat Islam terhadap Basuki Tjahaja Purnama alias Ahok yang beretnis Tionghoa dan beragama non Islam atau beragama Kristen dan juga mengakibatkan adanya reaksi dari masyarakat khususnya umat Islam yang dapat menimbulkan kebencian dan permusuhan yang menjurus pada terganggunya kerukunan antar umat beragama di Indonesia.

Dengan kata lain bahwa penegak hukum efektif dalam menangani tindakan propaganda kasus Basuki Tjahaja Purnama dan Buni Yani.

${ }^{42}$ Ibid

${ }^{43}$ Ibid

${ }^{44}$ Ibid 
3. Faktor sarana atau fasilitas yang mendukung penegakkan hukum Pada kasus Basuki Tjahaja Purnama dan Buni Yani terdapat barang bukti berupa dua versi video pidato Basuki Tjahaja Purnama tetapi penegak hukum tidak dapat menilai versi video pidato Basuki Tjahaja Purnama manakah yang dapat dikatakan sah dan asli dikarenakan kekurangan efektif sarana dan fasilitas yang dapat mendukung penegakkan hukum untuk membuktikannya. Hal tersebut pun menghalang kefektivitas penegak hukum dalam menangani kasus Basuki Tjahaja Purnama dan Buni Yani.

Selain itu, karena video pidato Basuki Tjahaja Purnama tidak dapat dibuktikan versi mana yang asli sehingga Buni Yani bebas dari pelanggaran Pasal 35 Undang-Undang Nomor 11 Tahun 2008 tentang Informasi dan Transaksi Elektronik yang berbunyi: ${ }^{45}$

"Setiap Orang dengan sengaja dan tanpa hak atau melawan hukum melakukan manipulasi, penciptaan, perubahan, penghilangan, pengrusakan Infromasi Elektronik dan/atau Dokumen Elektronik dengan tujuan agar Informasi Elektronik dan/atau Dokumen Elektronik tersebut dianggap seolah-olah data yang otentik."

Dalam hal penyebaran video pidato Basuki Tjahaja Purnama oleh Buni Yani dapat dicegah sebelum tersebar luas dan sebelum diterima baik oleh para pengguna media sosial online, akan tetapi karena tenaga manusia yang menghadapi informasi elektronik yang bersifat propaganda merupakan tanggung jawab dari Kementerian Komunikasi dan Informatika dan staf-staf Kementerian Komunikasi dan Informatika memiliki tugas dan tanggung jawab yang sangat banyak sehingga terjadi keterbatasan sumber daya manusia yang mengakibatkan kurang efektif untuk menganalisis dan menghadapi informasi elektronik yang bersifat propaganda yang tersebar cepat dan luas melalui media online yang seharusnya ditanggapi dengan cepat agar propagandis tidak dapat mencapai tujuannya.

\section{Faktor masyarakat}

Dalam pada kasus Basuki Tjahaja Purnama dan Buni Yani. Karena penyebaran video pidato Basuki Tjahaja Purnama yang dilakukan Buni Yani, masyarakat Indonesia sebagai penerima video tersebut masih tergolong banyak yang kurang berpengetahuan tentang propaganda mengakibatkan tidak mengetahui bahwa video tersebut yang diterima bersifat propaganda atau tidak dikarenakan teknik-teknik propaganda dilancarkan agar penerima video tersebut percaya akan apa yang propagandakan oleh propagandis tanpa harus melihat fakta dan tanpa perlu memeriksa atau mencari-cari bukti lagi. Selanjutnya, penerima video tersebut secara langsung membagi video tersebut ke orang lain melalui media sosial online. Dengan demikian, secara tidak sadar, mereka pun ikut serta menjadi propagandis dimana membagikan video tersebut kepada orang lain.

${ }^{45}$ Ibid 
Selain itu, Buni Yani merupakan seseorang dosen yang berintelektual dan terlatih. Dengan kelebihan tersebut, Buni Yani dapat memengaruhi massamassa masyarakat mengakibatkan masyarakat yang kurang berpengetahuan tentang propaganda menjadi gampang dipengaruhi oleh Buni Yani. Masyarakat pun menjadi kurang efektif dalam berpartisipasi untuk mencegah dari pengaruhnya video pidato Basuki Tjahaja Purnama yang disebarkan oleh Buni Yani.

\section{Faktor kebudayaan}

Kebudayaan masyarakat dalam penelitian ini adalah budaya masyarakat pengguna media-media sosial online. Media sosial didefinisikan sebagai sebuah media online, dengan para penggunanya bisa dengan mudah berpartisipasi, berbagi, dan menciptakan isi meliputi blog, jejaring sosial, wiki, forum dan dunia virtual. Blog, jejaring sosial dan wiki merupakan bentuk media sosial yang paling umum digunakan oleh masyarakat di seluruh dunia. ${ }^{46}$ Maka pengguna media sosial ini merupakan orang-orang yang ingin saling berkomunikasi dan saling berbagi informasi antara sesama pengguna. Pengguna media sosial ini mempunyai kebiasaan adalah membagikan informasi. Setiap informasi yang didapatkan oleh pengguna media sosial akan dibagikan kepada yang lain jika informasi tersebut menurutnya pantas untuk dibagikan. Dengan demikian, Buni Yani mengambil kesempatan tersebut untuk menyebarkan video pidato Basuki Tjahaja Purnama yang telah direkayasa dan dengan menambahkan caption lewat laman Facebook-nya untuk mempengaruhi para pengguna media sosial agar tercapai tujuannya.

Dalam hal ini, faktor kebudayaan juga kurang efektif dalam dalam berpartisipasi untuk mencegah dari pengaruhnya video pidato Basuki Tjahaja Purnama yang disebarkan oleh Buni Yani.

Faktor lain selain faktor hukum yang efektif untuk menangani persoalan propaganda di Indonesia adalah sebagai berikut:

1. Faktor hukumnya sendiri (undang-undang)

Dalam hal ini, Undang-Undang Nomor 11 Tahun 2008 tentang Informasi dan Transaksi Elektronik telah efektif dalam menangani persoalan propaganda di Indonesia khusus dalam kasus Basuki Tjahaja Purnama dan Buni Yani.

2. Faktor penegak hukum

Dalam hal ini, penegak hukum telah efektif dalam menangani persoalan propaganda di Indonesia khusus dalama kasus Basuki Tjahaja Purnama dan Buni Yani.

3. Faktor sarana atau fasilitas yang mendukung penegakkan hukum

Pemerintah dapat membuka tim atau departemen atau lembaga khusus yang dibawah pengawasan Kementerian Komunikasi dan Informatika agar dapat

${ }^{46}$ Errika Dwi Setya Watie, Komunikasi dan Media Sosial, Jurnal THE MESSENGER, Volume III No. 1, Juli 2011, hlm. 71. 
mengatasi keterbatasan pada tenaga manusia karena banyaknya tugas dan tanggung jawab yang harus ditangani oleh staf-staf Kementerian Komunikasi dan Informatika. Selain itu, juga dapat lebih memfokuskan diri dalam menganalisa dan menanggapi informasi elektronik yang bersifat propaganda secara efektif dan efesien seperti IPA (Institute for Propaganda Analysis) yaitu organisasi yang beroperasi di Amerika Serikat yang fokus pada permasalahan propaganda dosmetik yang mengancam kehidupan demokrasi. ${ }^{47}$

Pemerintah dapat mengembangkan teknologi aplikasi yang berguna untuk membuktikan suatu kebenaran dari informasi elektronik seperti video pidato Basuki Tjahaja Purnama yang memiliki dua versi. Dengan adanya pengembangan tersebut, dapat membantu penegak hukum lebih efektif dan efesien dalam melaksanakan pembuktian keaslian dan kebenaran dari suatu informasi elektronik.

Selain itu, pemerintah dapat memberikan sosialisasi pengetahuan tentang propaganda kepada masyarakat-masyarakat agar dapat mencegah dirinya dari pengaruh informasi elektronik yang bersifat propaganda dan juga dapat membuat spanduk jalanan yang akan mengingatkan kepada masyarakat untuk tetap waspada pada informasi elektronik yang bersifat propaganda.

\section{Faktor masyarakat}

Masyarakat sebagai penerima video pidato Basuki Tjahaja Purnama yang disebarkan oleh Buni Yani harus dapat membedakan apa itu fakta dan apa itu bohongan. Karena di masa yang akan datang, teknologi akan berkembang lebih maju daripada sekarang dan tindakan kriminalitas juga akan terus menerus muncul. Informasi-informasi elektronik akan menjadi senjata ampuh untuk dipropagandakan. Dalam hal ini, masyarakat jangan langsung percaya pada informasi-informasi yang diterimanya tetapi masyarakat harus mampu untuk mencari bukti kebenarannya tentang informasi elektronik yang diterimanya sebelum memutuskan untuk mempercayai informasi elektronik tersebut.

\section{Faktor kebudayaan}

Seperti yang telah disinggung sebelumnya, kebudayaan dari pengguna media sosial ini mempunyai kebiasaan adalah membagikan informasi. Jika keempat faktor, yaitu faktor hukum, faktor penegak hukum, faktor sarana dan fasilitas, dan faktor masyarakat telah mencapai efektif dan faktor kebudayaan ini akan menjadi pendukung dengan cara menggunakan kebiasaan pengguna media sosial untuk membagikan informasi elektronik yang tidak bersifat propaganda. Dengan ini, pengguna media sosial yang telah mengetahui bahwa informasi elektronik yang tersebar melalui media sosial online yang merupakan informasi elektronik yang bersifat propaganda maka pengguna media sosial yang mengetahui hal tersebut akan membagikan informasi ke pengguna lain agar tidak percaya pada informasi elektronik tersebut.

\footnotetext{
${ }^{47}$ Wikipedia, Institute for Propaganda Analysis, 2017. Diakses pada 21 Januari 2018 dari https://en.wikipedia.org/wiki/Institute_for_Propaganda_Analysis.
} 
Dengan demikian, kasus propaganda Buni Yani dapat dicegah dengan membagikan informasi yang menyatakan bahwa video pidato Basuki Tjahaja Purnama yang disebarkan oleh Buni Yani itu merupakan informasi elektronik yang bersifat propaganda agar pengguna media sosial online lainnya untuk tidak percaya pada informasi elektronik yang disebarkan oleh Buni Yani.

\section{E. Kesimpulan}

Setelah melakukan penelitian dan pembahasan mengenai efektivitas UndangUndang Nomor 11 Tahun 2008 tentang Informasi dan Transaksi Elektronik terhadap propaganda di Indonesia (Studi Kasus Basuki Tjahaja Purnama dan Buni Yani), maka kesimpulan yang didapatkan sebagai berikut:

a. Bahwa perbuatan Buni Yani terhadap Basuki Tjahaja Purnama dapat dikualifikasikan sebagai propaganda dengan memiliki karakteristik sebagai berikut:

1. Pesan atau informasi yang dikategorikan sebagai Informasi Elektronik

2. Propaganda yang sedang populer, dikemas bukan untuk menyenangkan secara intelektual.

3. Propaganda yang bertujuan.

4. Propaganda yang fleksibel, menyesuaikan diri dengan kondisi dan apa yang ingin dicapainya dengan pengetahuan.

5. Propaganda menggunakan metode yang layak.

6. Tercapainya tujuan propaganda atas perubahan sikap, pendapat, dan tindakan target propaganda sesuai yang dikehendaki propagandis.

7. Propaganda yang memiliki komponen propaganda.

8. Propaganda yang menggunakan teknik-teknik yang efektif sesuai dengan tujuan propaganda yang ingin dicapai.

b. Menurut teori efektivitas hukum Soekanto Soerjono untuk mengukur sejauh mana efektivitas Undang-Undang Nomor 11 Tahun 2008 Tentang Informasi dan Transaksi Elektronik dalam menangani persoalan propaganda di Indonesia khusus dalam kasus Basuki Tjahaja Purnama dan Buni Yani dengan faktor-faktor seperti faktor hukum dan faktor penegak hukum telah efektif sedangkan faktor sarana atau fasilitas yang mendukung penegakkan hukum, faktor masyarakat, dan faktor kebudayaan masih kurang efektif.

c. Harus dilakukan pengembangan terhadap faktor lain selain faktor hukum dan faktor penegak hukum yang efektif untuk menangani persoalan propaganda di Indonesia seperti pada faktor penegak hukum, faktor sarana atau fasilitas yang mendukung penegakkan hukum, faktor masyarakat, dan faktor kebudayaan agar dapat mengatasi informasi elektronik yang bersifat propaganda secara efektif dan efesien. 


\section{Buku}

\section{DAFTAR PUSTAKA}

Agus Cik, Dampak Pemberlakuan Perjanjian Penghindaran Pajak Berganda (P3B) Terhadap Investasi Negara Investor Asing Di Kota Batam, Tesis Magister Hukum, tidak diterbitkan, Universitas Internasional Batam, Kota Batam, 2017.

Ahmad M. Ramli, Cyber Law \& Haki Dalam Sistem Hukum Indonesia, Bandung: PT Refika Aditama, 2010.

Errika Dwi Setya Watie, Komunikasi dan Media Sosial, Jurnal THE MESSENGER, Volume III No. 1, Juli 2011.

I Made Pasek Diantha, Metodologi Penelitian Hukum Normatif Dalam Justifikasi Teori Hukum, Jakarta: Prenada Media Group, 2016.

Mohammad Shoelhi, Propaganda Dalam Komunikasi Internasional, Bandung: Simbiosa Rekatama Media, 2012.

Philemon Ginting, Kebijakan Penanggulangan Tindak Pidana Teknologi Informasi Melalui Hukum Pidana, Tesis Magister Hukum, tidak diterbitkan, Universitas Diponegoro, Semarang, 2008.

Soerjono Soekanto, Pengantar Penelitian Hukum, Jakarta: Penerbit Universitas Indonesia (UI-Press), 1986.

\section{Internet}

Dedy Rahmadi, Kasus Penistaan Agama Oleh Ahok Sehingga Dibui 2 Tahun, 2017. Diakses pada 20 Maret 2018 dari https://www.merdeka.com/peristiwa/kasus-penistaan-agama-oleh-ahokhingga-dibui-2-tahun.html.

Dody Indra Ramadhan, Caption Budi Yani di Facebook Disebut Sebarkan Permusuhan Sara, 2017. Diakses pada 7 Februari 2018 dari https://news.detik.com/berita/d-3528844/caption-buni-yani-di-facebookdisebut-sebarkan-permusuhansara?_ga=2.136144433.1020515559.1497238209-

1396309606.1497238209\&utm_medium=oa\&utm_campaign=detikcomso cmed\&utm_source=facebook\&utm_content=detikcom.

Gilang Fauzi, Kronologi Kasus Buni Yani, Penyebar Video Ahok Soal Al Maidah, 2016. Diakses pada 20 Maret 2018 dari https://www.cnnindonesia.com/nasional/20161124075029-12174911/kronologi-kasus-buni-yani-penyebar-video-ahok-soal-al-maidah. 
Kanavino Ahmad Rizqo, Perjalanan Kasus Buni Yani Sampai Jaksa Menuntut 2 Tahun Bui, 2017. Diakses pada 20 Maret 2018 dari https://news.detik.com/berita/d-3669426/perjalanan-kasus-buni-yanisampai-jaksa-menuntut-2-tahun-bui.

Kartika Anggraeni, Perjalanan Kasus Buni Yani Hingga Vonis 1,5 Tahun Bui, 2017. Diakses pada 20 Maret 2018 dari https://nasional.tempo.co/read/1033691/perjalanan-kasus-buni-yanihingga-vonis-15-tahun-bui.

Rita Ayuningtyas, Mengulik Kembali Perjalanan Kasus Ahok, 2018. Diakses pada 20 Maret 2018 dari http://news.liputan6.com/read/3322122/mengulikkembali-perjalanan-kasus-ahok.

Srihandriatmo Malau, Ini Kisah Perjalanan Kasus Ahok Hingga Vonis 2 Tahun Penjara, 2017. Diakses pada 20 Maret 2018 dari http://www.tribunnews.com/metropolitan/2017/05/09/ini-kisah-perjalanankasus-ahok-hingga-vonis-2-tahun-penjara.

Wikipedia, Institute for Propaganda Analysis, 2017. Diakses pada 21 Januari 2018 dari https://en.wikipedia.org/wiki/Institute_for_Propaganda_Analysis.

\section{Peraturan perundang-undangan}

Undang-Undang Nomor 11 Tahun 2008 tentang Informasi dan Transaksi Elektronik. 